\title{
War Impacts Studies Using Remote Sensing
}

\author{
Jwan Al-doski, Shattri.B Mansor, Helmi Zulhaidi Mohd Shafri \\ Department of Civil, Faculty of Engineering, Universiti Putra Malaysia, \\ 43400 UPM, Serdang, Selangor, Malaysia
}

\begin{abstract}
Since 1960, remote sensing satellite imagery reconnaissance has played a significant role in military operations by providing information concerning enemy missiles, troop deployments and military positioning using photographic images from lighter-than-air balloons to aircraft platforms and finally satellite remote sensing imagery with little attention given to broader war impacts. However, besides the war-related uses of such technology, many academic researchers have taken pains to use such advanced technology for examining war impacts. This paper highlights the applications of this technology for detecting war impacts.
\end{abstract}

Keywords: Satellite Imagery, Remote Sensing, War Impacts

\section{A. Remote sensing technology}

\section{INTRODUCTION}

The term "remote sensing," was first used in the United States in 1950 by Ms. Evelyn Pruitt of the U.S. Office of Naval Research. Remote Sensing (RS) is now commonly used to describe the science and art of obtaining information about an object, area, or phenomenon under investigation by a device that records the spectral properties of surface materials on the earth without actually coming into contact [1-2]. Basically, two types of remote sensing instruments are available: passive and active. Passive instruments detect the natural energy that is reflected or emitted from the observed scene whereas active instruments provide their own energy(electromagnetic radiation) to illuminate the object or scene.

Remote sensing from airborne and space-borne platforms provide a huge amount of valuable data about our earth's surface including aerial photographs, satellite images, spatial data set and other data [3]. The increased availability of mid- to fine-resolution satellite imagery since the early 1990s, offers repetitive data that vary among themselves in terms of spatial, radiometric, spectral, temporal resolution and its synoptic view [4]. Also, the digital format makes their data suitable for many computer image processing softwares. All these properties have made remotesense data the main source for various remote sensing applications [5-6-7].

\section{B. Remote Sensing Applications}

Remote sensing satellite imagery has provided the scientific community with an excellent opportunity to uncover the causes and consequences of land use/land cover changes when compared to the corresponding patterns of human activity [8]. Previous studies have used remote sensing data in many applications, notably in agricultural crop rotation [9], deforestation assessment [10], yield assessment [11], coastal zone changes [1213], land degradation detection [14], vegetation mapping [15], urban change detection [16] snow cover changes [17], vegetation changes [18-19], burned area mapping [20] and other applications. Recent advances in remote sensing and spatial analysis techniques have availed researchers of powerful tools for studying war impacts.

\section{REMOTE SENSING RULE IN STUDYING THE CONFLICTS}

Remote sensing satellite imagery has long been utilized to improve the effectiveness of military operations. Since 1960, satellite reconnaissance has played a significant role in providing information concerning enemy missiles, troop deployments and military positioning using photographic images from lighterthan-air balloons to aircraft platforms and finally satellite remote sensing imagery with little attention given to broader war impacts [21]. However, besides the war-related uses of such technology, many academic researchers have taken pains to use such advanced technology for examining war impacts [22].

The uses of satellite imagery in war's impact studies received much public attention during the 1991 Gulf War between Iraq and Kuwait, due to extensive interest in the war's environmental consequences spurred by the massive impacts resulting from vehicle movements, hundreds of oil well fires, and numerous oil lakes [23-24-25]. Since then, numerous researchers have utilized satellite imagery to show war impacts, initially concentrated on the immediate impacts of violence and military action by monitoring villages, urban infrastructure, housing, and urban built environment [26-27]. On the other hand, the mass displacement of local residents; re-vegetation of agricultural areas and construction of new service roads as a result of war lead to changes in land use and land cover which can be detected easily using remote sensing devices [28]. 
Numerous published studies used a remote sensing approach to examine the effects of war on land cover changes, but primarily paying attention to changes in vegetation health, abandoned agricultural land, agricultural land loss, vegetation land changes, and forest cover [29-30-31-32-33-34-35-36-37-38-39-40-41-4243]. Among the studies that utilized remote sensing data to analyze the war's effects by monitoring land cover changes are Suthakar and Bui (2008)applied post-classification method and GeographicalInformationSystems to monitor land use/land cover changes in the Jaffna Peninsula, northern Sri Lanka over the two decades from 1984 to early 2004. Over this period, the Jaffna Peninsula has been impacted severely by armed conflict. Results indicate that the land use/land cover pattern has been very dynamic since the early 1980 s, showing a remarkable decrease in agricultural land use and concomitant increase in non-agricultural land use. The ethnic conflict and its consequences, particularly large-scale population migrations, have been the main driving force for such land use/land cover [44]. Witmer in 2008, applied Landsat Thematic Mapper data and Quickbird imagery to study the effects of war on land use/land cover change in northeast Bosnia. Three change detection methods,namely; the multivariate alteration detection transformation, simple algebraic differencing, and supervised classificationtechniques were evaluated for their effectiveness in detecting LULC changes. The results of these analyses show that wars have a negative effect on abandoned agricultural land [36]. Maathuis in 2003, made a study of land cover changes and identified construction of service roads along minefields, vegetation removal from minefield perimeters, and vegetation regeneration of mined agricultural areas and mapped minefields using remotely sensed data in Zimbabwe [28].

In terms of assessing the war's damage caused to the environment, remote sensing data have shown the ability in detecting and indicating the impact of war on the environment For example, Veerabuthiran in 2011 used the LIDAR data for detection of biological warfare agents and toxic gases in the atmosphere [58]. Reuveny in 2010showed in his study the effects of warfare on the environment [59].

Recently, remote sensing satellite imageries have received attention from the Human Rights Watch organization and thus led to the highlighting of other new applications of satellite imagery on war impacts. In a unique study conducted by Witmer and O'Loughlin, thenighttime light imagery from the Defense Meteorological Satellite Program (DMSP) Operational Line-scan System (DMSP-OLS) satellite data were used to detect the effects of war in the Caucasus region of Russia and Georgia. The results showed that conflict-related events such as large fires that burn for weeks and large refugee movements are possible to detect, even with the relatively coarse spatial resolution $(2.7 \mathrm{~km})$ of the DMSP-OLS imagery [30]. Fine resolution satellite imagery such as IKONOS panchromatic $(1 \mathrm{~m})$ and JERS $(5-10 \mathrm{~m})$ has been used to count refugee tents to estimate populations at risk [45] and locate hidden water sources to site refugee camps for Sudanese in eastern Chad [46]. The Quickbird imagery (60cm resolution) from 2002 and 2006 was used to document the repressive actions of the Zimbabwean government in the destruction of dwellings [47].

$\begin{array}{lllll}\text { Furthermore, } & \text { WorldView-1 and } & \text { Formosat-2 imagery }\end{array}$ (http://unosat.web.cern.ch/unosat/)showed burning and destroyed homes after the August 2008 fighting during the ethnic cleansing of ethnic Georgian villages in South Ossetia. The humanitarian use of satellite data is for finding displaced persons fleeing conflict zones and relocating them to large refugee camps, where international assistance can be more easily administered and accessed. For this purpose, remote sensing, which has been increasingly used to monitor the spatial extent of these camps for more efficient aid management, population estimates, and impacts to adjacent forests [43-48-49].

\section{WAR IMPACT STUDIES IN IRAQ}

During the last thirty years of the $20^{\text {th }}$ century, Iraq in particular has been deeply and disproportionately affected by several conflicts, from the Iran-Iraq War,, the Gulf War and the initial campaign of Operation Iraqi Freedom (OIF), to economic warfare in the form of comprehensive United Nations (UN) sanctions, to the longterm occupation and reconstruction of OIF, and post invasion [56]. In spite of these many wars that Iraq has been involved in, very few researches have been carried out to demonstrate the capacity of remote sensing in showing the effects of these wars. The Gulf War between Iraq and Kuwait, was one of the first large scale environmental disasters that was closely monitored by remote sensing technology such as multiple sensors from relatively coarse AVHRR imagery to finer spatial resolution Landsat and SPOT data, which were used to map, evaluate, and monitor changes dealing with urban development, vegetation, coastal wetlands, and sand sheet surface differences and to document the effects of the 1991 Gulf War in terms of oil lakes, oil spills, burning oil wells and military vehicle movements [23-24-39-50-51-52]. Further analyses were also used to identify the distribution of burning wells in different oilfields and produced estimates of flow rates and emissions of gaseous pollutants and particulates by incorporating the different spatial and temporal resolutions of AVHRR, Meteosat, Landsat Thematic Mapper, and SPOT data [50-54].

Remote sensing satellites were used to document the war's impact on the environment in Iraq. Multispectral imagery of Landsat and IKONOS was applied by UNEP in 2003 to show the effects of the oil trench fires on the environment around Baghdad in March 2003 at the start of the second US-Iraq conflict [60]. Xian in 2006 introduced in his study, the ability of two kinds of meteorological satellite data, geostationary orbit 
satellite and polar orbit satellite (FY-1C/LDPT) data and the Metosate-5 images to analyze the huge dust storm that happened in the middle of the Arabian Peninsula from 25-27 March 2003, in the course of the Iraq war, which shows that weather condition is one of the important parameters in Modern warfare [54]. Koch in 1998, used multi-source and multi-scale data derived from satellite images, land form/surface maps, and field observations to identify and characterize changes in the desert surface of Kuwait resulting from military activities during and after the Gulf War of 1991 by applying geographic information system (GIS) techniques. These changes produce alterations to the surface sediment and morphological features that lead to environmental degradation [55].

Besides this, remote sensing data also offer unrivaled utility in detection, monitoring and quantifying the changes in land use and land cover in Iraq. Gibson in 2012 used time-series Landsat TM and ETM+ imagery to create multi-temporal normalized difference vegetation index (NDVI) data to identify and quantify changes in agricultural land use and compare cultivated area and abandoned land as an effect of war in central Iraq during four conflicts (Iran-Iraq War from 1980 to 1988, Gulf War from 1990 to 1991, UN Sanctions from 1990 to 2003, and Operation Iraqi Freedom from 2003 to 2011) [56]. UNEP (2010) used decision tree analysis to classify multi-temporal Landsat TM and ETM+ imagery to monitor the cultivated area in central Iraq, during three decades of war. Brasington in 2002 applied satellite imagery as well to document the effects of war on the Mesopotamian Marshlands in the southern part of Iraq [61].Also, the effect of war on land vegetative cover in Saudi Arabia was studied due to the second Gulf War [57].

\section{CONCLUSION}

Remote sensing technology will continue to be an important resource for a growing body of research using remote sensing imagery to study war and its effects and observing its effect on land cover in current and future conflict and war regions. However, from the previous studies, remote sensing instruments are still surprisingly limited to study war and conflict impacts and still the ability of satellite imagery for detecting war impacts such as: bullet-pocked walls, abandoned buildings and individual mines are limited and difficult due to spatial, spectral and temporal characteristics of the data. Further studies are neededto look at new applications of remote sensing in war impacts studies.

\section{ACKNOWLEDGEMENT}

I would like to thank Prof, Dr. Shattri.B Mansor for his support and encouragement. Thanks are also extended to Dr. Helmi Zululhaidi. Bin Mohd Shafri. Extended thanks go to University Putra Malaysia staff for their support and cooperation.

\section{REFERENCES}

[1] A. Singh, "Digital change detection techniques using remotely-sensed data," Int. J. Remote Sens., vol. 10, pp. 989-1003, 1989.

[2] J. Rogan and D. M. Chen, "Remote sensing technology for mapping and monitoring land-cover and land-use change," Progress in Planning, vol. 61, pp. 301-326, 2004.

[3] C. Paradzayi, H. Annegarn, R. Matsika and B. Erasmus, "Field surveys for biomass assessment in African savanna woodlands," in Geoscience and Remote Sensing Symposium, 2008.IGARSS 2008.IEEE International, 2008, pp. III-632-III-635.

[4] W. Stoney, "Guide to land imaging satellites," American Society for Photogrammetry and Remote Sensing.Updated February, vol. 2, pp. 2006, 2006.

[5] D. Lu, E. Moran, S. Hetrick and G. Li, "Land-Use and Land-Cover Change Detection," Advances in Environmental Remote Sensing: Sensors, Algorithms, and Applications, vol. 7, pp. 273, 2010.

[6] D. Lu, P. Mausel, E. Brondízio and E. Moran, "Change detection techniques," Int. J. Remote Sens., vol. 25, pp. 2365-2407, 2004.

[7] R. E. Kennedy, P. A. Townsend, J. E. Gross, W. B. Cohen, P. Bolstad, Y. Wang and P. Adams, "Remote sensing change detection tools for natural resource managers: Understanding concepts and tradeoffs in the design of landscape monitoring projects," Remote Sens. Environ., vol. 113, pp. 1382-1396, 2009.

[8] J. A. Cardille and J. A. Foley, "Agricultural land-use change in Brazilian Amazonia between 1980 and 1995: evidence from integrated satellite and census data," Remote Sens. Environ., vol. 87, pp. 551-562, 2003.

[9] R. D. Macleod and R. G. Congalton, "A quantitative comparison of change-detection algorithms for monitoring eelgrass from remotely sensed data," Photogramm. Eng. Remote Sensing, vol. 64, pp. 207-216, 1998.

[10] T. N. K. D. Binh, N. Vromant, N. T. Hung, L. Hens and E. Boon, "Land cover changes between 1968 and 2003 in Cai Nuoc, Ca Mau peninsula, Vietnam," Environ. Dev. Sustainability, vol. 7, pp. 519-536, 2005.

[11] P. V. K. Rao, V. V. Rao and L. Venkataratnam, "Remote sensing: A technology for assessment of sugarcane crop acreage and yield," Sugar Tech, vol. 4, pp. 97-101, 2002.

[12] B. Kesgin and E. Nurlu, "Land cover changes on the coastal zone of Candarli Bay, Turkey using remotely sensed data," Environ. Monit.Assess., vol. 157, pp. 89-96, 2009.

[13] HongquanXie, Yanyan Zhang and Xia Lu, "Land use/cover change study of lianyungang coastal zone based on remote sensing," in Geoinformatics, 2011 19th International Conference on, 2011, pp. $1-5$.

[14] A. M. Fadhil, "Land degradation detection using Geo-information technology for some sites in Iraq," Journal of Al-Nahrain University-Science (JNUS), vol. 12, pp. 94-108, 2009.

[15] J. Müllerová, "Use of digital aerial photography for sub-alpine vegetation mapping: A case study from the Krkonoše Mts., Czech Republic," Plant Ecol., vol. 175, pp. 259-272, 2005.

[16] L. Martínez, V. Palà, R. Arbiol, L. Pineda and M. Joaniquet, "Urban change detection on satellite images series.application to catalunya area," in Urban Remote Sensing Joint Event, 2007, 2007, pp. 1-5. 
[17] G. Singh and G. Venkataraman, "LOS PALSAR data analysis of snow cover area in himalayan region using four component scattering decomposition technique," in Recent Advances in Microwave Theory and Applications, 2008. MICROWAVE 2008. International Conference on, 2008, pp. 772-774.

[18] GepingLuo and Xi Chen, "Vegetation change during 1990-2000 and its response to climate change in the northern slope of Tianshan mountains," in Geoscience and Remote Sensing Symposium, 2004.IGARSS '04.Proceedings. 2004 IEEE International, 2004, pp. 3440-3443 vol.5.

[19] X. Chen, M. T. Jabbar, X. Cai, Z. Wu and Y. Liang, "Detection and evaluation of vegetation change and urbanization in the cen tral china," in Geoscience and Remote Sensing Symposium, 2005. IGARSS'05.Proceedings.2005 IEEE International, 2005, pp. 4 pp.

[20] I. Z. Gitas, G. H. Mitri and G. Ventura, "Object-based image classification for burned area mapping of Creus Cape, Spain, using NOAA-AVHRR imagery," Remote Sens. Environ., vol. 92, pp. 409-413, 2004.

[21] M. W. Corson and E. J. Palka, "Geotechnology, the US military, and war," Geography and Technology, pp. 401-427, 2004.

[22] A. De Sherbinin, D. Balk, K. Yager, M. Jaiteh, F. Pozzi, C. Giri and A. Wannedo, "A CIESIN thematic guide to social science applications of remote sensing," CIESIN Thematic Guides, 2002.

[23] G. Stephens and M. Matson, "Monitoring the Persian Gulf war with NOAA AVHRR data," Int. J. Remote Sens., vol. 14, pp. 1423$1429,1993$.

[24] F. El-Baz, Gulf War and the Environment.Routledge, 1994.

[25] H. I. El- Gamily, "Utilization of multi- dates LANDSAT_TM data to detect and quantify the environmental damages in the southeastern region of Kuwait from 1990 to 1991," Int. J. Remote Sens., vol. 28, pp. 1773-1788, 2007.

[26] J. J. Sulik and S. Edwards, "Feature extraction for Darfur: geospatial applications in the documentation of human rights abuses," Int. J. Remote Sens., vol. 31, pp. 2521-2533, 2010.

[27] D. Al-Khudhairy, I. Caravaggi and S. Glada, "Structural damage assessments from Ikonos data using change detection, objectoriented segmentation, and classification techniques," Photogramm. Eng. Remote Sensing, vol. 71, pp. 825, 2005.

[28] B. Maathuis, "Remote sensing based detection of minefields," Geocarto Int., vol. 18, pp. 51-60, 2003.

[29] J. O'Loughlin and F. D. Witmer, "The localized geographies of violence in the North Caucasus of Russia, 1999-2007," Ann. Assoc. Am. Geogr., vol. 101, pp. 178-201, 2011.

[30] F. D. W. Witmer and J. O'Loughlin, "Detecting the Effects of Wars in the Caucasus Regions of Russia and Georgia Using Radiometrically Normalized DMSP-OLS Nighttime Lights Imagery," GIScience\& Remote Sensing, vol. 48, pp. 478-500, 2011.

[31] J. O'Loughlin, F. D. Witmer and A. M. Linke, "The Afghanistan-Pakistan Wars, 2008-2009: Micro-geographies, Conflict Diffusion, and Clusters of Violence," Eurasian Geography and Economics, vol. 51, pp. 437-471, 2010.

[32] A. Fatehi and N. Jalali, "Effects of polluted rainfall related to burning Kuwaiti oil wells on vegetation in south of Iran," International Archives of Photogrammetry and Remote Sensing, vol. 33, pp. 427-432, 2000.

[33] K. Stevens, L. Campbell, G. Urquhart, D. Kramer and J. Qi, "Examining complexities of forest cover change during armed conflict on Nicaragua's Atlantic Coast," Biodivers. Conserv., vol. 20, pp. 2597-2613, 2011.

[34] H. De Vos, J. Jongerden and J. Van Etten, "Images of war: using satellite images for human rights monitoring in Turkish Kurdistan1," Disasters, vol. 32, pp. 449-466, 2008.

[35] F. D. W. Witmer and J. O'Loughlin, "Satellite data methods and application in the evaluation of war outcomes: Abandoned agricultural land in Bosnia-Herzegovina after the 1992-1995 conflict," Ann. Assoc. Am. Geogr., vol. 99, pp. 1033-1044, 2009.

[36] F. D. W. Witmer, "Detecting war- induced abandoned agricultural land in northeast Bosnia using multispectral, multitemporal Landsat TM imagery," Int. J. Remote Sens., vol. 29, pp. 3805-3831, 2008.

[37] M. H. Bagour, "Environmental Impact Assessment of 1991 Gulf War Military Activities Using Landsat Tm Imageries," Journal of Applied Sciences Research, vol. 2, pp. 1228-1234, 2006.

[38] R. Schimmer, Tracking the Genocide in Darfur: Population Displacement as Recorded by Remote Sensing. Yale Center for International and Area Studies, 2008.

[39] R. S. Williams, J. Heckman and J. Schneeberger, Environmental Consequences of the Persian Gulf War, 1990-1991: RemoteSensing Datasets of Kuwait and Environs. National Geographic Society, 1991.

[40] I. A. Brown, "Assessing eco-scarcity as a cause of the outbreak of conflict in Darfur: a remote sensing approach," Int. J. Remote Sens., vol. 31, pp. 2513-2520, 2010.

[41] G. Forkuor and O. Cofie, "Dynamics of land-use and land-cover change in Freetown, Sierra Leone and its effects on urban and periurban agriculture-a remote sensing approach," Int. J. Remote Sens., vol. 32, pp. 1017-1037, 2011.

[42] P. M. Thu and J. Populus, "Status and changes of mangrove forest in Mekong Delta: Case study in Tar Vinh, Vietnam," Estuar. Coast.Shelf Sci., vol. 71, pp. 98-109, 2007.

[43] M. A. Lodhi, F. R. Echavarria and C. Keithley, "Using remote sensing data to monitor land cover changes near Afghan refugee camps in northern Pakistan," Geocarto Int., vol. 13, pp. 33-39, 1998.

[44] K. Suthakar and E. N. Bui, "Land use/cover changes in the war- ravaged Jaffna Peninsula, Sri Lanka, 1984-early 2004," Singapore Journal of Tropical Geography, vol. 29, pp. 205-220, 2008.

[45] S. Giada, T. De Groeve, D. Ehrlich and P. Soille, "Information extraction from very high resolution satellite imagery over Lukole refugee camp, Tanzania," Int. J. Remote Sens., vol. 24, pp. 4251-4266, 2003.

[46] P. Bally, J. Bequignon, O. Arino and S. Briggs, "Remote Sensing and Humanitarian Aid- A life-saving combination," E.S.A.Bulletin, pp. 36-41, 2005.

[47] E. Lempinen, "Pioneering AAAS project finds strong evidence of Zimbabwe repression," American Association for the Advancement of Science (AAAS).Available Online at: Http://www.Aaas.org/news/releases/2006/0530zim. Shtml (Accessed 5 March 2008), 2006.

[48] E. Bjorgo, "Using very high spatial resolution multispectral satellite sensor imagery to monitor refugee camps," Int. J. Remote Sens., vol. 21, pp. 611-616, 2000 .

[49] E. Bjorgo, "Refugee camp mapping using very high spatial resolution satellite sensor images," Geocarto Int., vol. 15, pp. 79-88, 2000 .

[50] T. Husain, "Kuwaiti oil fires-Source estimates and plume characterization," Atmos. Environ., vol. 28, pp. $2149-2158,1994$.

[51] A. Y. Kwarteng, "Multitemporal remote sensing data analysis of Kuwait's oil lakes," Environ. Int., vol. 24, pp. 121-137, 1998.

[52] N. Jalali, A. Noroozi and A. Abkar, "Tracking of Oil Spills and Smoke Plumes of Kuwait's Oil Well Fires to the Coast and Territory of IR of Iran as a Result of the 1991 Arabian Gulf War," Isbn, vol. 90, pp. 1489, 1998.

[53] A. Abuelgasim, W. Ross, S. Gopal and C. Woodcock, "Change detection using adaptive fuzzy neural networks: environmental damage assessment after the Gulf War," Remote Sens. Environ., vol. 70, pp. 208-223, 1999.

[54] D. Xian, A. Sun and X. Zheng, "Analyzing the dust storm in iraq using meteorological satellite data during the iraq war," in Proceedings of SPIE, 2006, pp. 62000U. 
[55] M. Koch and F. El-Baz, "Identifying the effects of the Gulf War on the geomorphic features of Kuwait by remote sensing and GIS," Photogramm. Eng. Remote Sensing, vol. 64, pp. 739-746, 1998.

[56] G. R. Gibson, "Three Decades of Agricultural Land Use and Land Cover Change in Iraq," War and Agriculture: Three Decades of Agricultural Land use and Land Cover Change in Iraq, 2012.

[57] M. Bagour, S. Al-Mahlafe, A. Jacob, A. Fahsi and T. Ghabour, "Remote Sensing To Assess Changes In Land Vegetative Cover In Saudi Arabia Due To The Second Gulf War,"

[58] S. Veerabuthiran and A. Razdan, "LIDAR for Detection of Chemical and Biological Warfare Agents," Def. Sci. J., vol. 61, pp. 241$250,2011$.

[59] R. Reuveny, A. S. Mihalache-O'Keef and Q. Li, "The effect of warfare on the environment," J. Peace Res., vol. 47, pp. 749-761, 2010.

[60] United Nations (UN), 2003. Oil-for-Food fact sheet, URL: http://www.un.org/Depts/oip/background/fact-sheet.html, (last date accessed: 21 November 2003)

[61] J. Brasington, "Monitoring marshland degradation using multispectral remote sensed imagery," The Iraqi Marshlands: A Human and Environmental Study. London: Politico's, pp. 151-168, 2002. 